\title{
The Relationship Between State Aid and Nuclear Energy and A Legal Analysis of Nuclear Energy State Aid Cases in Terms of European Union State Aid Rules
}

\author{
Ahmet Sefa Dinleyici* ${ }^{*}$ (1)
}

\begin{abstract}
State aid to the nuclear energy sector has increased significantly within the last decade and in parallel to this increase, controversy about giving state aid to nuclear energy has soared. In addition to this controversy, the existence of a special treaty for nuclear energy, called the Euratom Treaty, exclusion of nuclear energy from the 'Guidelines on State aid for environmental protection and energy 2014-2020' and very intrinsic risks and market failures related to the nuclear energy sector distinguish nuclear state aid cases from other energy state aid cases. Considering the scarcity of research dealing with increasing nuclear state aid cases in detail, this research intended to focus on the relationship between state aid and nuclear energy and analyse prominent nuclear state aid cases. During the research, prominent nuclear state aid cases which have shaped the case law and related legislations were analysed. It could be briefly concluded that nuclear state aid cases will likely continue to increase as energy markets become more competitive. But it is very clear that intrinsic risks of nuclear energy and related market failures stemming from imperfect market conditions are keenly appreciated by the European Commission and the European Courts, and nuclear cases are treated more leniently in line with these conditions. This sends a very clear message that the lenient approach of the Commission and the Courts toward the nuclear state aid cases will remain as long as market failures and the Euratom Treaty exist and in this regard, the absence of guidelines for nuclear energy, while it seems like a disadvantage, will ensure the needed flexibility of the Commission when making its state aid assessment in nuclear state aid cases.
\end{abstract}

\section{Keywords}

State Aid, Nuclear Energy, Euratom Treaty, European Commission, Competitionse

Devlet Yardımları ve Nükleer Enerji İlişkisi ve Avrupa Birliği Devlet Yardımı Kuralları Bakımından Nükleer Enerji Devlet Yardımı Davalarının Hukuksal İncelemesi

\section{Öz}

Avrupa Birliği rekabet hukuku, diğer fonksiyonlarının yanında, "Ortak Pazar" oluşturmayı hedefler ve bu pazarda özel teşebbüsler yahut üye devletler eliyle oluşabilecek saptırmaları engellemeye çalışır. Devletlerin yapabileceği saptırmalar ise "Devlet Yardımı Kuralları" marifetiyle kontrol altına alınmaya çalışılır. Bu bakımdan Avrupa Birliği içerisinde geliştirilen devlet yardımları kontrol sistemi benzeri neredeyse olmayan ve gelişmiş bir sistemdir. Avrupa Komisyonu tarafindan yayınlanan son devlet yardımı tablosuna göre üye devletlerin devlet yardımı harcamaları 2013 yılından bu yana artmaktadır. Devlet yardımı harcamaları arasında ise enerji sektörü en fazla yardım alanlar sektör konumundadır. Ancak devlet yardımı kuralları

+ Bu makale yazarın Türkiye Cumhuriyeti Milli Eğitim Bakanlığı bursu kapsamında Dundee Üniversitesi'nde $2019-2020$ yıllarında gerçekleşen "Uluslararası Enerji Hukuku ve Politikası" alanındaki yüksek lisans tezinden üretilmiştir. Makalede ifade edilen fikirler yazara ait olup, Türkiye Cumhuriyeti Enerji ve Tabii Kaynaklar Bakanlığı'nın görüşlerini yansıtmamaktadır.

* Corresponding author: Ahmet Sefa Dinleyici (Legal Advisor) (LL.M), Republic of Turkey Ministry of Energy and Natural Resources, Ankara, Turkey. E-mail: asafadinleyici@gmail.com ORCID: 0000-0002-6538-4258

To cite this article: Dinleyici AS, "The Relationship Between State Aid and Nuclear Energy and A Legal Analysis of Nuclear Energy State Aid Cases in Terms of European Union State Aid Rules" (2021) 79(3) İstanbul Hukuk Mecmuası 1029. https://doi.org/10.26650/mecmua.2021.79.3.1911 
açısından nükleer enerjiye yapılan devlet yardımları diğer enerji kaynaklarına yapılan devlet yardımlarından farklılık arz etmekte ve çeşitli sebeplerden dolayı hususi inceleme gerektirmektedir. Literatürde bugüne değin bazı önemli nükleer enerji devlet yardımları tek tek ele alınmış yahut nükleer enerji konusu devlet yardımını konu alan önemli akademik çalışmalarda yeterince detaya inilmeden yalnızca bir alt bölüm olarak zikredilmiştir. Bu durum dikkate alınarak çalışmamızda nükleer enerji sektörü ve devlet yardımı ilişkisi ele alınarak ve nükleer enerji devlet yardımlarının içtihad hukukunda nasıl değerlendirildiği ve içtihad hukukunun müdahil taraflara berrak bir manzara arz edip etmediği incelenmiştir. Yapılan tüm incelemeler ışığında nükleer enerji sektörüne uygulanacak devlet yardımı kuralları konusunun büyük ölçüde yerleştiği görülmektedir. Bu kapsamda enerji piyasaları daha fazla rekabetçi hale geldikçe nükleer enerji devlet yardımı davalarının da artış gösterebileceği beklenebilir. Ancak Avrupa Komisyonu ve Mahkemeler, nükleer enerji özelinde oluşan riskleri ve buna bağlı olarak gelişen piyasa aksaklıklarını dikkate alarak nükleer devlet yardımı davalarını daha esnek olarak ele almaktadır. Nükleer enerjiye özgü riskler, piyasa aksaklıkları ve en temelde Euratom Anlaşması yürürlükte olduğu müddetçe bu esnek yaklaşımın devam edeceği açıkça görülmektedir. Bu konuda bir kılavuzun olmayışı ilk bakışta bir dezavantaj olarak görülse de, bu durum Avrupa Komisyonu'na gelecekte nükleer enerjiye yapılacak devlet yardımlarını incelerken gerekli esnekliği sağlamada en önemli faktör olmaya devam edecektir.

\section{Anahtar Kelimeler}

Devlet Yardımı, Nükleer Enerji, Euratom Anlaşması, Avrupa Komisyonu, Rekabet

\section{Extended Summary}

Uncompetitive behaviours of states are controlled through state aid rules. These state aid rules essentially serve to protect internal markets by limiting states' market distortive aid measures. According to the latest state aid scoreboard published by the European Commission, state aid spending of Member States has increased since 2013. Within state aid spending, the energy sector is one the sectors receiving most aid and is the source of serious controversies between Member States.

However, nuclear energy stands out among other types of energy sources and requires particular examination in terms of state aid rules for several reasons. First, it can easily be noticed that numbers of state aid cases to nuclear energy sector have increased significantly within the last decade and could be expected to increase more in the future. Second, the existence of the Euratom Treaty and accompanying issue of the applicability of state aid rules to nuclear energy sector place nuclear state aid cases in a very special position. In addition, nuclear energy is excluded from the 2014 Environmental Protection and Energy Guidelines though it had originally been included in its draft. Moreover, it has been seen that several state aid decisions of the Commission regarding the nuclear energy sector were challenged by other Member States, a situation which has been encountered very rarely within state aid control history. On the very contrary to these negative attitudes toward nuclear state aid, the Commission and European Courts have treated it differently and showed a very lenient approach in nuclear state aid cases.

Given the increasing importance of nuclear energy state aid cases and the growing controversy around these cases, there is an increased need to deal with nuclear state aid case law as a whole to understand accurately how the Commission and the Courts assessed the relationship between state aid and nuclear energy in those cases. 
In the Germany Contingency Reserves case, the content of selectivity, one of the main requirements of establishing state aid, was clarified. It was explicitly reiterated that incidentally providing more benefits for one undertaking from the state measure which applied equally to all undertakings does not necessarily make the state measure selective. Accordingly, it was settled that the important thing which prevents state measures from being selective is to set equal criteria for undertakings to benefit from state measure instead of dealing with them as if all undertakings equally benefited from the state measure.

In British Energy decisions, the increasing necessity of state aid for nuclear power plants as energy markets become more competitive was clearly noticed. It has been understood that low prices and a lack of financial instruments, which could hedge market risks for a long time, could expose nuclear power plant operators to unbearable challenges, as was the case for British Energy. After the British Energy decisions, as expected, numbers of nuclear state aid cases have soared due to rising numbers of various risks stemming from increasingly competitive energy market conditions.

The most important advancement of state aid law was achieved thanks to long EDF cases by which the scope of private investor test was widened. After the EDF cases, it was settled that, even if state measures were regulatory measures, the Commission will have to investigate if a private investor test is applicable. In other words, the Commission will have to look at the effect of the measure, not its form of. In the same vein after the EDF cases, the Commission has taken a very important decision in Hungary Paks II as to the content of the private investor test and showed how the private investor test should be applied within nuclear energy state aid cases, taking into consideration the uncertainties of the nuclear energy sector in order to attain more accurate results.

When it comes to most controversial case of nuclear state aid history, the Hinkley case, the main discussions were around the separation of investment and operating aid. While state measures for Hinkley, such as CfD, at first glance, seemed to be operating aid, the Commission decided to look deep inside and then accepted these measures as if they were investment aid. As these state measures were accepted as investment aid, they were found compatible with state aid rules. It has to be accepted that the Commission's effect-based stance is a very important advancement within case law, and it is likely to encourage other states to use different state aid mechanisms similar to CfD in order to minimise risks for private investors.

Considering all of the above, the issue of the application of state aid rules to nuclear energy sector is now mostly settled and, nuclear state aids will continue to be controlled under state aid rules taking into account the objectives of the Euratom Treaty. It could be expected that nuclear state aid cases will likely continue to increase 
as energy markets become more competitive. But it is very clear that the intrinsic risks of nuclear energy and related market failures stemming from imperfect market conditions are keenly appreciated by the Commission and the Courts, and nuclear cases are treated more leniently in line with these conditions. This sends a very clear message that the lenient approach of the Commission and the Courts toward the nuclear state aid cases will remain as long as market failures and the Euratom treaty exist and in this regard, the absence of guidelines for nuclear energy, while it seems like a disadvantage, will ensure the needed flexibility of the Commission when making its state aid assessment in nuclear state aid cases.

\section{Introduction}

European Union (EU) competition law, in addition to its various functions, aims to facilitate the EU internal market ${ }^{1}$ and prevent distortions caused by private undertakings or Member States. ${ }^{2}$ Uncompetitive behaviours of private undertakings are controlled through antitrust and merger regulations. ${ }^{3}$ Meanwhile, uncompetitive behaviours of states are controlled through state aid rules. ${ }^{4}$ These state aid rules essentially serve to protect internal markets by limiting states' market distortive aid measures. ${ }^{5}$ Currently, this highly developed system of EU state aid control is very unique and cannot be compared to any other state aid control in the world. ${ }^{6}$

According to the latest state aid scoreboard published by the European Commission (the Commission), state aid spending of Member States has increased since 2013. ${ }^{7}$ Reasons for this state aid spending range from furthering social or regional objectives ${ }^{8}$ to supporting national companies ${ }^{9}$ or responding to the devastating effects of financial crises ${ }^{10}$. In line with these various objectives behind giving state aid, the aims of state aid control also range from avoiding subsidy races between Member States ${ }^{11}$ to create a level playing field for undertakings or to protect internal market from distortions. ${ }^{12}$

Within state aid spending, the energy sector is one of the sectors receiving most

Richard Whish and David Bailey, Competition Law ( $8^{\text {th }}$ edn, Oxford University Press 2015) 23-24

Cosmo Graham, EU and UK Competition Law ( $2^{\text {nd }}$ edn, Pearson 2010) 11

Whish and Bailey (n 1) 53

ibid

Ignacio Herrera Anchustegui and Christian Bergqvist, 'The role of State aid law in energy' in Tina Hunters and others (eds), Handbook of Energy Law (Routledge 2020) 124

6 Andrea Biondi, 'Some Reflections on the Notion of "State Resources" in European Community State Aid Law' (2006) 30 Fordham Int'l L.J. 1426, 1428

7 European Commission, 'State Aid Scoreboard 2019' $12<$ https://ec.europa.eu/competition/state_aid/scoreboard/state_aid_ scoreboard_2019.pdf> accessed 19 August 2020

8 Piet Jan Slot, 'EU State Aids Law' in Dennis Patterson and Anna Södersten (eds), A Companion to European Union Law and International Law (Wiley 2016) 334

9 ibid

10 Kelyn Bacon, European Union Law of State Aid ( $3^{\text {rd }}$ edn, Oxford University Press 2017) 8

$11 \quad$ ibid 9

12 ibid 10 
aid $^{13}$ and is the source of serious controversies between Member States. ${ }^{14}$ It is no surprise that the very important cases which developed the state aid law originated from the energy area. ${ }^{15}$ In accordance with this growing importance and attention on energy state aid cases, state aid to the energy sector was for the first time explicitly covered in one of the guidelines of the Commission. ${ }^{16}$

However, nuclear energy stands out among different types of energy sources and requires particular examination in terms of state aid rules for several reasons. First, it can easily be noticed that numbers of state aid cases to the nuclear energy sector have increased significantly within the last decade and could be expected to increase more in the future. Second, the existence of the Euratom Treaty and accompanying issue of the applicability of state aid rules to the nuclear energy sector place nuclear state aid cases in a very special position. In addition, nuclear energy is excluded from the 2014 Environmental Protection and Energy Guidelines though it had been included in its original draft. ${ }^{17}$ Moreover, it has been seen that several state aid decisions of the Commission regarding nuclear energy sector were challenged by other Member States, a situation which is encountered very rarely within state aid control history. ${ }^{18}$ On the very contrary to these negative attitudes toward nuclear state aid, the Commission and European Courts (the Courts), as it will be detailed in section 3.2, have treated them differently and showed a very lenient approach in nuclear state aid cases.

In the literature, some important nuclear state aid cases were examined separately ${ }^{19}$ or nuclear energy was reviewed as a subsection in certain seminal state aid books without getting into more detail on the relation between state aid rules and nuclear energy sector. ${ }^{20}$ However, given the increasing importance of nuclear energy state aid cases and the growing controversy around these cases, there is now an increased need to deal with nuclear state aid case law as a whole to accurately understand how the

13 European Commission, 'Scoreboard 2019' (n 7) 4

14 Falk Schoning and Clemens Ziegler, 'What is State Aid?' in Leigh Hancher and others (eds), State Aid and the Energy Sector (Bloomsbury 2018) 54

15 Case C-379/98 PreussenElektra AG v Schhleswag AG [2001] ECR I-2159; Case C-124/10 P. European Commission v Électricité de France (EDF) [2012] ECLI:EU:C: 2012:318.

16 Guidelines on State aid for environmental protection and energy 2014-2020 [2014] OJ C 200

17 Erika Szyszczak, 'State aid for energy infrastructure and nuclear power projects' (2015) 16 ERA Forum 25, 28

18 Case T-356/15 Republic of Austria v European Commission [2018] ECLI:EU: T: 2018:439; Case T-101/18 Action brought on 21 February 2018 - Austria v Commission [2018] OJ C 152

19 Dörte Fouquet, 'The Hinkley Point C Judgment of the General Court in view of a changing internal electricity market' (2018) 9 (1) Renewable Energy Law and Policy Review 35; Dietmar O. Reich, 'No Level Playing Field for Nuclear Power Reserves?: Comment on the Judgment in Case T-92/02 of 26 January 2006' (2006) 5(2) European State Aid Law Quarterly 445; Erika Szyszczak, 'The Survival of the Market Economic Investor Principle in Liberalised Markets' (2011) 10(1) European State Aid Law Quarterly 35; Phedon Nicolaides, 'The Compatibility of State Aid with the Internal Market: Annotation on the Judgment of the General Court (Fifth Chamber) of 12 July 2018 in Case T-356/15 Republic of Austria v European Commission' (2018) 17(4) European State Aid Law Quarterly 534

20 Leigh Hancher and Max Klasse, 'Aid to Nuclear and Coal' in in Leigh Hancher and others (eds), State Aid and the Energy Sector (Bloomsbury 2018); Leigh Hancher and Francesco Salerno, 'Coal and Nuclear Aid' in Christopher Jones (ed), EU Energy Law, Volume II: Competition Law and Energy Markets ( $5^{\text {th }}$ edn, Claeys \& Casteels 2019) 
Commission and the Courts assessed the relationship between state aid and nuclear energy in those cases.

Therefore, in this dissertation, the relationship between state aid and the nuclear energy sector will be discussed and it will be asked how nuclear state aid cases have been dealt with and if the case law provides a clear outlook for involved parties. Considering the limits of the research, only prominent nuclear state aid cases which have shaped the case law will be analysed in terms of their important points and the nuclear public procurement cases which have sometimes been dealt together with state aid cases will be excluded from the scope of this research.

In the next part of the dissertation, the state aid law of the EU and main discussions will be reviewed in order to better understand the grounds of the nuclear state aid cases. In the third part, first, the necessity of state aid to nuclear energy sector and the application of state aid rules for the nuclear energy sector will be deeply discussed. Then, nuclear state aid cases will be analysed. In the last part, key findings of the case law will be summarised and the outlook for future nuclear state aid cases will be given in light of the analyses.

\section{EU State Aid Rules}

\subsection{Development of State Aid Rules}

Primary state aid rules of EU are laid down over Articles 107 and 109 of Treaty on the Functioning of the European Union (TFEU). Article 107(1) sets out what constitutes state aid, and certain aid categories which shall be compatible are specified in article 107(2) and certain aid categories which may be found compatible by the Commission are specified in article 107(3). Article 108 is concerned with the enforcement of state aid control and article 109 explains the role of the European Council regarding regulations.

While the wording of the state aid rules has been kept substantially the same from the beginning of state aid control, ${ }^{21}$ its content has evolved significantly through the interpretations of the Courts. ${ }^{22}$ In particular, the functional interpretation of concepts such as the concept of undertaking or the concept of aid have eased this evolution. ${ }^{23}$ In accordance with this functional approach, even the very fundamental concept of state aid has not been defined precisely in TFEU.

21 Only difference between the Article 92(1) of Treaty Establishing the European Economic Community and the Article 107(1) of Treaty on the Functioning of the European Union is using of common market term instead of internal market.

22 Cecilie Fanøe Petersen, Award of Public Contracts as a Means to Conferring State Aid: A Legal Analysis of the Interface Between Public Procurement Law and State Aid Law (PhD series Number 10.2018, Copenhagen Business School 2018) 67

23 Andrea Biondi and Elisabetta Righini, 'An Evolutionary Theory of State Aid Control' in Damian Chalmers and Anthony Arnull (eds), The Oxford Handbook of European Union Law (Oxford University Press 2015) 5 
State aid is a wider concept than subsidy, because state aid could be both in the form of direct payment (as in the case of subsidy) but also a way of easing the burden that undertaking normally would create.

${ }^{24}$ At the same time, the concept of state aid is an objective concept ${ }^{25}$ which means that the form or intention of aid do not matter, rather, what does matter is the effect of the measure. ${ }^{26}$ If any state measure meets the criteria set out in article 107(1), then any argument of public interest or public prerogative for avoiding state aid control will be of no avail. ${ }^{27}$ This objective concept of state aid, for instance, plays a very significant role in dealing with state aids which are covered under the scheme of tax regulations. ${ }^{28}$ It would have been difficult to effectively prevent the circumvention of state aid rules if this functional interpretation and objective concept of state aid had not been used.

The interpretation of the state aid concept outlined in article 107(1) is carried out by the Courts and the Commission decides if the state measure in question involves state aid within the boundaries of the Court's interpretations. ${ }^{29}$ The only discretion the Commission has is in article 107(3), where it makes compatibility assessments of certain state aid categories. ${ }^{30}$ Therefore, the Commission usually published guidelines where it showed how it would use its discretionary powers under article 107(3). . $^{31}$

However, the Commission, for the first time, issued a notice in which it set forth its understanding of the state aid concept, mainly based on the case law, in order to give clarity regarding the concept. ${ }^{32}$ It is undeniable that the Notice has presented a clear compilation of case law as to the basic elements of the state aid concept. The Notice not only gives us clues about the Commission's understanding, but it also provides a perspective on how state aid case law has evolved. If the Notice had been published earlier, it might have been more helpful given the clarity it has provided since the publication. However, along with its unusual features, this notice is problematic in terms of legal aspects because it can be seen that the Commission has provided its

24 Case 30/59 De Gezamenlijke Steenkolenmijnen in Limburg v High Authority of the European Coal and Steel Community [1961] ECR 1, 19

25 Case C-83/98 P French Republic v Ladbroke Racing Ltd and Commission of the European Communities [2000] EU:C:2000: 248, para 25

26 Case 173-73 Italian Republic v Commission of the European Communities [1974] E.C.R. 709, para 13

27 Schoning and Ziegler (n 14) 55

28 Kelyn Bacon, 'State Aids and General Measures' (1997) 17(1) Yearbook of European Law 269, 271

29 Andrea Biondi and Oana Stefan, 'The Notice on the Notion of State Aid: Every Light Has Its Shadow' in Bruno Nascimbene and Alessia Di Pascale (eds), The Modernisation of State Aid for Economic and Social Development (Studies in European Economic Law and Regulation 14, Springer 2018) 50

30 ibid

31 ibid

32 Commission Notice on the notion of State aid as referred to in Article 107(1) of the Treaty on the Functioning of the European Union [2016] OJ C 262 (The Notice on the notion of State Aid) 
own understanding based on its own decision practice regarding some points where the EU case law has not yet developed. ${ }^{33}$ While, in doing so, the Commission claimed that its interpretations are without prejudice to the EU Courts' interpretations, this notice by the Commission is likely to shape the development of state aid concept. Therefore, it would have been more proper for the Commission to remain silent on issues which the case law has not yet developed.

\subsection{Elements of State Aid}

The content of state aid is not defined concretely. Any aid which has the elements set out in the article will be deemed, in principle, incompatible state aid. These elements are laid down in Article 107(1) of TFEU as follows:

Save as otherwise provided in the Treaties, any aid granted by a Member State or through State resources in any form whatsoever which distorts or threatens to distort competition by favouring certain undertakings or the production of certain goods shall, in so far as it affects trade between Member States, be incompatible with the internal market. ${ }^{34}$

\subsubsection{State Origin}

The element of state origin refers to the phrase of 'any aid granted by Member State or through State resources' in article 107(1). When read literally, it implies that the conditions of 'granting aid by a Member State' or 'through state resources' are alternatives and if one of them is met, then state origin element is established. However, the Courts have interpreted these conditions cumulatively since the early cases. ${ }^{35}$ Despite the clear wording of the article, the Courts insisted on this narrow interpretation and decisively interpreted two conditions cumulatively in the famous case of Preussen Elektra. ${ }^{36}$

As a result of the narrow interpretation accepted by the Courts, which requires both state action and using of state resources to establish state origin element, states may avoid state aid control by using private funds for granting state aid to undertakings. Therefore, this narrow interpretation has been severely criticised because of the reason that it may dampen state aid control and it may give rise to a circumvention of state aid rules by states. ${ }^{37}$

\footnotetext{
Biondi and Stefan (n 29) 51

${ }^{34}$ Consolidated version of the Treaty on the Functioning of the European Union [2012] OJ C 326

35 Marianne Clayton and Maria J Segura Catalan, 'The Notion of State Resources: So Near and yet So Far' (2015) 14(2) European State Aid Law Quarterly 260, 260

36 Case C-379/98 Preussen Elektra AG v Schhleswag AG [2001] ECR I-2159 para 58

${ }^{37}$ Erika Szyszczak, 'Criterion of State Origin' in Herwig C H Hofmann and Claire Micheau (eds), State Aid Law of the European Union (Oxford University Press 2016) 66
} 
In order to minimise circumvention problems related to the narrow interpretation, the first element of state origin, state resources, is defined extensively. ${ }^{38}$ In that sense, state resources mainly cover state budgets including the resources of public undertakings. ${ }^{39}$ Even state commitment may fall under the scope of state resources. ${ }^{40}$ It also covers private resources when they come under public control even if they do not become permanent assets of state budget. ${ }^{41}$ Moreover, using of state resources does not have to be a direct transfer of state resources to the recipient, but it may also be an indirect transfer of state resources. For example, if a state foregoes its revenue or sells something under its value or exempts certain undertakings from tax, this would be indirectly using state resources. ${ }^{42}$

Using state resources as a second constituent of state origin element must be attributable to the state. For ascertaining this, it is asked if public authorities were involved. ${ }^{43}$ Where the aid is given directly by public authorities, i.e., through legislation, imputability can be automatically deducted. ${ }^{44}$ But, when aid comes from the resources of publicly owned undertakings, it must be thoroughly examined if this aid is attributable to the state. ${ }^{45}$ Therefore, aid given by public undertakings cannot be imputed to the state in a straightforward manner. Imputability may only be inferred in cases where some indicators exist. ${ }^{46}$ For instance, if a public undertaking cannot make a decision without considering the requirements of the state or if the supervision over the decisions of public undertakings is very strict, then aid given by public undertakings could be imputed to the state. In other words, what is important in the imputability issue is to find the actual influence over public undertaking.

\subsubsection{Selectivity}

Another necessary element of state aid is selectivity, in that any aid granted by the state must favour 'certain undertakings or the production of certain goods.' In that sense, aid given under the scheme of general legislative or regulatory measures will

\footnotetext{
Bacon, European Union Law of State Aid (n 10) 62

39 The Notice on the notion of State Aid (n 32) paras 48-49

40 ibid para 51

$41 \quad$ ibid para 57

42 ibid para 51

43 Case C-482/99 French Republic v Commission of the European Communities [2002] European Court Reports 2002 I-04397, para 52

44 Case T-358/94 Compagnie Nationale Air France v Commission of the European Communities [1996] ECR II-02109, para 59

45 The Notice on the notion of State Aid (n 32) para 40

46 French Republic (n 43) paras 55-56
} 
not meet selectivity requirements and therefore will not be state aid. ${ }^{47}$ In essence, selectivity criterion distinguishes general measures from state aids. ${ }^{48}$

Basically, the Courts assess selectivity under two categories, namely, regional and material. For regional selectivity, although the Courts have established principles especially for selective tax measures, ${ }^{49}$ these principles could be easily applied to all regional selectivity issues. According to these principles, any aid which is only applied for the specific region of the Member State, in principle, will be selective. ${ }^{50}$ However, as established by the Courts, if the region has institutional, procedural, and financial autonomy, state measures applied to that specific region may avoid being selective. ${ }^{51}$ As regional state aid cases are rare and related principles are clear-cut, it could be expected that regional selectivity will not bring out many disputes in the future.

On the other hand, material selectivity covers all selective measures apart from regional selective measures. In other words, any aid granted specifically to certain undertakings or sectors are assessed under material selectivity. ${ }^{52}$ In this regard, material selectivity can occur either de jure or de facto. ${ }^{53}$ If selectivity results from pre-established selective criteria provided to favour only certain undertakings, this could be assessed as being de jure selective. ${ }^{54}$ In contrast, if selectivity results from the misapplication or misinterpretation of objective and general criteria, then it could be assessed as being de facto selectivity. ${ }^{55}$ De facto selectivity will likely occur where authorities have a wide margin of discretion in applying general state measures. ${ }^{56}$

The case law regarding the selectivity element has been criticised with respect to its allegedly broad scope. ${ }^{57}$ In other words, it is argued that selectivity is so wide that any state measure could easily be assessed as being selective. However, contrary to this criticism, it could be claimed that the scope of selectivity has been significantly narrowed down by the Courts. First, aid does not have to be applied to all undertakings in the country in order to avoid being selective. Aid will only be selective if it

47 Bacon, 'State Aids and General Measures' (n 28) 290

48 Miro Prek and Silvère Lefèvre, 'The Requirement of Selectivity in the Recent Case-Law of the Court of Justice' (2012) 11(2) European State Aid Law Quarterly 335, 335

49 The Notice on the notion of State Aid (n 32) para 143

50 Andreas Bartosch, 'The Concept of Selectivity' in Erika Szyszczak (ed), Research Handbook on European State Aid Law (Edward Elgar 2011) 176

51 Case C-88/03 Portuguese Republic v Commission of the European Communities [2006] ECR I-07115, para 67

52 The Notice on the notion of State Aid (n 32) para 120

53 Anna Nykiel-Mateo and Joachim Wiemann, 'Selectivity' in Nicola Pesaresi and others (eds), EU Competition Law (Volume 4 Book 1, $2^{\text {nd }}$ edn, Claeys Casteels 2016) 268

54 ibid

55 ibid

56 Case C-241/94 French Republic v Commission of the European Communities [1996] ECR I-04551, paras 23-24

57 Nykiel-Mateo and Wiemann (n 53) 263 
discriminates undertakings which are in a 'comparable factual and legal situation'. ${ }^{58}$ Whether or not these undertakings are in a comparable factual and legal situation is discovered in light of the objective pursued by the granting of aid. ${ }^{59}$ Therefore, aid to certain undertakings will not be automatically selective unless it discriminates undertakings under a comparable situation, which is, therefore, significantly narrowing the scope of selectivity. As another narrowing step, it has been established that even discriminative aids between comparable undertakings could escape from being selective if they can be justified by the nature or the general scheme of the discriminative aid. ${ }^{60}$ But, this justification must be related to the internal functioning of system, not to the objectives attributed externally. ${ }^{61}$

\subsubsection{Advantage}

The third constituent element of state aid is the existence of advantage, in other words, in order to be state aid, aid given by state resources to certain undertakings must provide economic benefits which undertakings could not have obtained under market conditions. ${ }^{62}$ Advantage, in this regard, does not only refer to positive economic benefits i.e., giving direct subsidy, but also easing the cost of the undertaking i.e., tax exemptions may be deemed as an advantage. ${ }^{63}$ At first glance, to discern if there is an advantage may seem so easy but discovering the existence of advantage is not always straightforward because states may sometimes be involved in commercial activities, such as giving loans to undertakings and these activities could be in line with market conditions. ${ }^{64}$ If the transaction of state is in line with market conditions, then there would be no advantage. In order to distinguish states' commercial acts in line with normal market conditions from pure state aids, the 'market economy investor principle' (MEIP) was invented. ${ }^{65}$

MEIP, which is not explicitly mentioned in the TFEU, is applied with the interpretation of Article 345 of the TFEU which allows states to be involved in commercial activities under equal terms with private undertakings. ${ }^{66}$ This principle was first used in Commission practice and then became a principle recognised by

\footnotetext{
Case C-487/06 P British Aggregates Association v Commission of the European Communities and United Kingdom [2008] ECR I-10515, para 82

59 Joined Cases C-78/08 to C-80/08 Ministero dell'Economia e delle Finanze and Others v Paint Graphos Soc. coop. arl and Others [2011] ECR I-07611, para 49

60 The Notice on the notion of State Aid (n 32) para 138

61 ibid

62 C-39/94 Syndicat français de l'Express international (SFEI) and others v La Poste and others [1996] ECR I-3547, para 60

${ }_{63}$ Aindrias Ó Caoimh and Wolf Sauter, 'Criterion of Advantage' in Herwig C H Hofmann and Claire Micheau (eds), State Aid Law of the European Union (Oxford University Press 2016) 85

64 The Notice on the notion of State Aid (n 32) para 73

65 ibid para 74

${ }^{66}$ Samuel Cornella, 'The Market Economy Investor Principle to Evaluate State Aid: Latest Developments and New Perspectives’ (2015) 22 Maastricht J Eur \& Comp L 553, 555
} 
the Courts. ${ }^{67}$ While this principle, at the beginning, was applied in the investment activities of states, i.e., capital injections, the principle was then extended to cover different commercial activities, ${ }^{68}$ thus, the principle is sometimes known as the 'market economy operator' (MEO) test. ${ }^{69}$

In MEIP, commercial activity of a state is analysed in terms of determining what would be the behaviour of hypothetical private investors in the same situation. As a first option, the behaviour of hypothetical investors could be determined when state activity is carried out simultaneously with private investors, called 'pari passu', or when given commercial activity is carried out through competitive tender procedure. ${ }^{70}$ If so, it could be inferred that a state's commercial activity is, in principle, in line with market conditions and there is no advantage. However, in the absence of pari passu or tender procedure, if benchmarking with comparable hypothetical private investors could still be established, then it may also make commercial state activity in line with MEIP. ${ }^{71}$ When doing the benchmarking with a comparable hypothetical private investor, this private investor must be rational and prudent. ${ }^{72}$ The investor does not have to be seeking short term profit maximisation, but, at least, must seek to make revenue in the long term. ${ }^{73} \mathrm{~A}$ state which claims its commercial activity is in line with a comparable private investor must support this claim with indicators showing that the state sought to make profit before taking its investment decision. ${ }^{74}$ Whether a state's commercial activity is in line with market conditions cannot be determined only by looking at ex poste profits. Finally, if benchmarking with a comparable hypothetical private investor is not possible, the last option is to use other assessment methods, i.e., calculating the internal rate of return of commercial activity and comparing it with normal rate of return for such activity carried in market conditions. ${ }^{75}$

While MEIP seems a well-developed test to distinguish a state's commercial activities from state aids, in practical terms it is not always possible to find appropriate private investors to compare because even the behaviours of prudent private investors may range in market conditions. ${ }^{76}$ In the same vein, calculating rate of returns, demonstrated as a last option, may not always reflect accurate rates of returns in

\footnotetext{
7 Juan Jorge Piernas López, The Concept of State Aid Under EU Law: From internal market to competition and beyond (Oxford University Press 2015), ch4, 9

68 Md. Rezaul Karim, 'The EU Market Economy Investor Principle: A Good Paradigm?' (2014), 13 <https://papers.ssrn.com/ sol3/papers.cfm?abstract_id=2498873 $>$ accessed 21 August 2020

69 The Notice on the notion of State Aid (n 32) para 75

70 Cornella (n 66) 567

1 ibid 569

2 Anchustegui and Bergqvist (n 5) 129

ibid

74 The Notice on the notion of State Aid (n 32) para 78

75 Bacon, European Union Law of State Aid (n 10) 40

76 Karim (n 68) 16
} 
normal market conditions. ${ }^{77}$ One possible way to ease the practical problems of MEIP could be to use different benchmarks and assessment methods together to get more accurate results as private investor behaviours.

\subsubsection{Distortion of Competition and Effect on Trade Between Member States}

Lastly, any aid granted by the state from state resources which gives selective advantage must 'distort or threaten to distort competition' and 'affect trade between Member States'. These two conditions are usually examined together ${ }^{78}$ but they are distinct conditions in that aid which distorts competition may not necessarily affect trade between Member States. ${ }^{79}$ Mostly, these conditions are easily met as the thresholds for establishing these conditions have been constantly kept low by the Courts. ${ }^{80}$ For meeting the requirement of distortion of competition, the Commission does not make a detailed relevant market analysis. ${ }^{81}$ If aid merely improves the competitive position of undertaking compared to its competing undertakings, aid will be deemed as distortive. ${ }^{82}$ For example, aid which relives an undertaking's day to day operation costs is likely to improve its competitive position and, thus, will be deemed as distortive.

Concerning the requirement of effect on trade between Member States, this does not have to be actually effect. It is sufficient to be capable of affecting trade between states. ${ }^{83}$ But, the Commission must state the reasons why such a measure is capable of affecting the trade. ${ }^{84}$ Effects on trade do not have to be substantial or appreciable, in that even a small amount of aid could affect trade. ${ }^{85}$ However, it must be noted that the Commission applies specific 'de minimis rule', removing aids under certain amounts from its state aid control. ${ }^{86}$ Though this specific de minimis rule is based on the Commission's discretion on economic assessment, ${ }^{87}$ it needs to be revisited because even very small aids in local areas could significantly affect trade.

84 Joined cases T-447/93, T-448/93 and T-449/93 Associazione Italiana Tecnico Economica del Cemento and British Cement Association and Blue Circle Industries plc and Castle Cement Ltd and The Rugby Goup plc and Titan Cement Company SA $v$ Commission of the European Communities [1995] II-01971, para 140

85 Case T-214/95 Het Vlaamse Gewest (Flemish Region) v Commission of the European Communities [1998] II-00717, para 48

86 Commission Regulation (EU) No 1407/2013 of 18 December 2013 on the application of Articles 107 and 108 of the Treaty on the Functioning of the European Union to de minimis aid Text with EEA relevance [2013] 
In its Notice, the Commission clarified its understanding of the requirement of effect on trade. According to it, the Commission first looks to see if the recipient of aid is involved in cross-border trade activity. ${ }^{88}$ If so, then it could be inferred that aid is liable to affect trade between Member States. But if aid recipient is not involved in cross-border activity, this does not automatically close the investigation for the Commission. The Commission will then investigate if such aid improves the position of the undertaking, making it more difficult for other undertakings in other Member States to enter the market. ${ }^{89}$ If the aid makes it difficult for other undertakings to enter the market, then this will again be deemed as affecting trade between Member States. While the approach taken by the Commission is not strictly based on the Courts' practice and has been criticised for this reason, ${ }^{90}$ it must be stated that this approach is does not bring any novelty or new interpretation, rather it only refines the case law on this issue.

\subsection{Conditions of Compatibility}

\subsubsection{Compatibility Conditions in Article 107(3) of the TFEU}

Any aid which has the elements set out in article 107(1), in principle, will be deemed as incompatible state aid. Considering various possible justifying reasons behind giving state aid, there has not been laid down complete state aid prohibition. But what has been provided are certain conditions in article 107(2) which make state aid compatible and conditions in article 107(3) which may make state aid compatible. In essence, article 107(2) and 107(3) which set out compatibility conditions could be viewed as a compromise between protection of internal market through state aid control and a state's right of pursuing public objectives by giving state aid.

Article 107(2) lays down 'de jure' compatibility conditions in that the Commission must find these sorts of state aids compatible because the article uses the phrase "the following shall be compatible with the internal market". ${ }^{91}$ Aids given in unusual circumstances, such as for natural disasters or social aids given to individuals fall under the scope of article 107(2). The Commission has no margin of discretion in finding these aids compatible if they meet other requirements in the article. ${ }^{92} \mathrm{On}$ the contrary, article 107(3) uses the phrase 'the following may be considered to be compatible' which gives the Commission a wide margin of discretion in appreciating

\footnotetext{
The Notice on the notion of State Aid (n 32) para 191 
the compatibility of certain aid categories. ${ }^{93}$ In making its compatibility assessment, the Commission has exclusive competence and the Court's review is limited in this respect. ${ }^{94}$

The Commission has published some guidelines for certain aid categories in which it specified how its compatibility assessment will be conducted based on article 107(3). In these guidelines, the Commission provided specific compatibility assessment principles. These guidelines include, for example, 'Guidelines on State aid for environmental protection and energy 2014-2020', ${ }^{55}$ 'Guidelines on regional State aid for 2014-2020'. ${ }^{96}$ The reason behind publishing these guidelines is to give clarity as to the compatibility assessment of the Commission. ${ }^{97}$ Actually, these guidelines may be regarded as self-limiting by the Commission's own discretion. ${ }^{98}$ In doing so, the Commission is creating legitimate expectation and therefore cannot, in principle, depart from its guidelines. ${ }^{99}$

While at the beginning there was no consistency between different Commission guidelines, with the modernisation process of state aid control, compatibility assessment principles have been streamlined, and these streamlined principles have been inserted into different Commission guidelines. ${ }^{100}$ These assessment principles are: contribution to a well-defined objective of common interest, need for state intervention, appropriateness of the aid measure, incentive effect, proportionality, avoidance of undue negative effects on competition and trade between Member States and transparency. ${ }^{101}$ It must be noted that if certain aid is not covered in one of the guidelines, the Commission will apply article 107(3) directly for the compatibility assessment. ${ }^{102}$ For example, state aid to nuclear concerns is usually assessed directly under article 107(3)(c) as it is not covered in the 'Guidelines on State aid for environmental protection and energy 2014-2020'.

\subsubsection{Compatibility Conditions in Article 106(2) of TFEU}

In addition to the compatibility conditions set out in article 107(2) and 107(3), another compatibility condition is laid down in article 106(2) which provides that

\footnotetext{
93 Antonios Bouchagiar, 'The Binding Effects of Guidelines on the Compatibility of State Aid: How Hard is the ${ }^{\mathrm{Co}}$ mmission's Soft Law?' (2017) 8(3) Journal of European Competition Law \& Practice 157, 157

94 ibid

95 Communication from the Commission - Guidelines on State aid for environmental protection and energy 2014-2020 [2014] OJ C 200/01 (Guideline for environmental protection and energy 2014-2020)

96 Guidelines on regional State aid for 2014-2020 Text with EEA relevance [2013] OJ C 209

97 Bacon, European Union Law of State Aid (n 10) 103

98 ibid 103

99 ibid 103-104

100 Leigh Hancher and others, EU State Aids ( $5^{\text {th }}$ edn, Sweet \& Maxwell 2016) para 4-052

101 ibid

102 Bacon, European Union Law of State Aid (n 10) 99
} 
undertakings entrusted with services of general economic interest (SGEI) are subject to state aid rules in so far as these rules do not obstruct their performance of services. In this regard, article 106(2) could be seen as a key concept between Member States' rights to pursue their public policy objectives and protection of internal market conditions. ${ }^{103}$ If article 106(2) had not been provided, the state would have been troubled by state aid rules when they tried to pursue public policies through compensating their SGEI entrusted undertakings. Thanks to this article, states can entrust their undertakings with SGEI and compensate their costs accordingly in accordance with the conditions of the article 106(2).

One problem is that services of general economic interest have not been defined precisely and thus determining what constitutes SGEI depends on the wide discretion of Member States. ${ }^{104}$ These are generally considered as services which cannot be provided sufficiently in normal market conditions, in other words, which are not profitable for private undertakings. ${ }^{105}$ Considering the public interest entrusted to these unprofitable services, states compensate the losses of these undertakings. At this stage, state aid control comes into play for this state compensation and the Commission assesses these compensations under article 106(2).

The Commission has published the SGEI Decision ${ }^{106}$ and SGEI Framework ${ }^{107}$ by which it explained and clarified how the compatibility assessment under article 106(2) will be made. In the SGEI Decision, SGEI compensations for certain categories and/or under certain amounts are exempted, and thereby there is no need for any authorisation from the Commission. ${ }^{108}$ However, if such compensation is not covered by the SGEI Decision, then it must be notified and examined by the Commission under the SGEI Framework. ${ }^{109}$

When making its examination under the SGEI Framework, the Commission first checks if there is a genuine and clearly defined SGEI. ${ }^{110}$ The assessment of the

103 Wolf Sauter, 'The Criterion of Advantage in State Aid: Altmark and Services of General Economic Interest' (2014) 3-4< https://ssrn.com/abstract $=2426230>$ accessed 22 August 2020

104 Jorge Padilla and Urs Haegler, 'Compensation for SGEI: An Economist's Look at the Altmark Test and the Community Framework' in Jacques Derenne and Massimo Merola (eds), Economic Analysis of State Aid Rules- Contributions and Limits- (Lexxion 2007) 82

105 Communication from the Commission on the application of the European Union State aid rules to compensation granted for the provision of services of general economic interest Text with EEA relevance [2012] OJ C 8/02 SGEI Communication, paras 47-48

106 2012/21/EU: Commission Decision of 20 December 2011 on the application of Article 106(2) of the Treaty on the Functioning of the European Union to State aid in the form of public service compensation granted to certain undertakings entrusted with the operation of services of general economic interest (notified under document C(2011) 9380) Text with EEA relevance [2011] OJ L 7 (SGEI Decision)

107 Communication from the Commission - European Union framework for State aid in the form of public service compensation (2011) Text with EEA relevance [2012] OJ C 8/03 (SGEI Framework)

108 SGEI Decision, article 2

109 SGEI framework, para 7

110 ibid para 13 
Commission is limited to checking if there is any manifest error in defining the SGEI, that is, if there exists any genuine market failure which requires states to intervene and compensate these undertakings. ${ }^{111}$ Then, the Commission checks if compensation parameters were established beforehand so that compensation does not exceed what is necessary. ${ }^{12}$ After all, this compensation will be found compatible with state aid rules if compensation for undertaking entrusted with SGEI complies with public procurement rules and other related conditions set out in the Framework.

\section{The Nuclear Energy Sector and State Aid}

State aid has been given in different forms to the nuclear energy sector. ${ }^{113}$ The main reason behind constantly giving state aid to this sector is related to the intrinsic risks of the sector. States, in order to alleviate these risks and promote nuclear development, have been inclined to use different forms of state aids throughout the development of the nuclear energy sector. In that sense, three different risks which affect the sector very deeply can be identified - market risk, construction risk and political risk. ${ }^{114}$

With respect to market risk, nuclear power plants require very significant investment cost and very low operation cost, therefore they must be operated as much as possible to recover their significant investment costs. ${ }^{115}$ Thus, nuclear power plants have less flexibility to stop their operation when prices are low, making nuclear power plants very vulnerable to low prices. ${ }^{116}$ Construction risk is also very high due to the poor track record of construction estimates because most of the nuclear projects have encountered significant cost overruns. ${ }^{117}$ Lastly, political risk is an important risk factor in nuclear energy sector due to serious controversy regarding its safety perception. ${ }^{118}$ Even one accident on one side of the world may lead to the closure of plants on the other side, or a successive government may cancel nuclear projects which were executed by its predecessor due to the politically sensitive nature of nuclear energy. ${ }^{119}$ While these risks, especially political risk, are more or less also valid for other energy sources, a longer operational lifetime ranging from 60 years to 80 years makes these risks more intensified and deterring. ${ }^{120}$

111 ibid

112 ibid paras 21-50

113 Stephen Tromans, 'State support for nuclear new build' (2019) 12(1) The Journal of World Energy Law \& Business 36, 36

114 ibid 38

115 Steve Thomas, The Economics of Nuclear Power: An Update (Publication Series on Economy, Heinrich-Böll-Stiftung 2010) 16

116 Steve Thomas, 'Competitive energy markets and nuclear power: Can we have both, do we want either?' (2010) 38 Energy Policy 4903, 4904

117 ibid

118 Nicole Robins and Tridevi Chakma, 'State Aid in Energy under the Spotlight' (2016) 15(2) European State Aid Law Quarterly 247, 252

119 ibid 253

120 Catalin Gabriel Stanescu, 'Stabilization Mechanisms for Nuclear Investments vs. Electricity Market Liberalization: The Case of Contract for Difference. Lessons from the United Kingdom and Romania' (2018) 27(6) European Energy and Environmental Law Review 223, 223 
With the liberalisation of energy markets, all intrinsic risks of the nuclear energy sector have become more evident. Private investors, due to a lack of corresponding hedging instruments, cannot now bear these risks in liberalised markets which significantly increases the need for state aid. ${ }^{121}$ For example, while the average operational life of a nuclear plant is about 60 years, price hedging instruments that go beyond 20 years are not available for alleviating related market price risks for nuclear energy. ${ }^{122}$ In order to ease these market risks for private investors, for example, the UK has given state aid through the 'Contract for Difference Mechanism' for ensuring revenue stability for private nuclear investors. ${ }^{123}$

In addition to the various risks of nuclear energy which have increased the need of state aid, market failures caused by imperfect energy market conditions are also important factors behind granting huge amounts of state aids to the nuclear sector. The market is imperfect in terms of securing energy supply in that the value of ensuring the security of a supply is not adequately priced and this brings out problems in competitive energy markets. ${ }^{124}$ In addition, a market fails in terms of incentivising low carbon energy sources as it does not adequately take into account the negative externalities of fossil fuels. ${ }^{125}$ These two market failures affect nuclear energy very badly, as nuclear energy is an important low carbon energy source and it provides security of supply. States, therefore, intervene to correct these failures through granting state aids such as in the form of capacity payments to nuclear power plants. ${ }^{126}$

\subsection{Application of State Aid Rules to Nuclear Energy}

Application of competition law and, in particular, state aid rules to nuclear energy is a very controversial issue due to the existence of a specific treaty concerning nuclear energy, The Treaty establishing the European Atomic Energy Community Treaty (Euratom Treaty). ${ }^{127}$ The Euratom Treaty is one of the foundational treaties of the European Community and seeks to promote and facilitate the nuclear development within Europe. ${ }^{128}$ According to Article 106a(3) of Euratom, the provisions of TFEU cannot derogate from Euratom, placing the Euratom Treaty in lex specialis position with respect to nuclear energy.

\footnotetext{
121 Robins and Chakma (n 118) 252

122 ibid

123 Support to Hinkley Point C Nuclear Power Station (2014/C 69/06) Commission Decision SA.34947 [2014] OJ C/69, paras 6-48 (Hinkley Decision)

124 Thomas, 'Competitive energy markets and nuclear power' (n 116) 4906

125 Stephen Tromans, 'Subsidies for Nuclear Power in the UK: Putting the Debate into the Context' (2014) $11<$ https:// www.39essex.com/docs/articles/nuclear_power_and_subsidies_january_2014_final.pdf $>$ accessed 22 August 2020

126 Thomas, 'Competitive energy markets and nuclear power' (n 116) 4906

127 Miguel Sousa Ferro, 'Competition Law and the Nuclear Sector: An EU Outlook' (2011) 2010(2) Nuclear Law Bulletin 13,

${ }^{128}$ Consolidated version of the Treaty establishing the European Atomic Energy Community [2012] OJ C 327, art 2
} 
However, the Commission has applied state aid rules to nuclear energy when state aid distorts competition. ${ }^{129}$ Considering the fact that Euratom does not contain rules regarding state aid, the application of TFEU will not cause any derogation problem as long as it takes into account the objectives of Euratom. As the decisions of the Commission have mostly not been challenged, the Courts have not been able to find a chance to provide their views on this issue. ${ }^{130}$ But, in the recent Hinkley Point $\mathrm{C}$ power plant nuclear state aid case, which was challenged by Austria, the Court has provided its concurring views with the Commission and accepted the application of state aid rules in line with the objectives of Euratom. ${ }^{131}$

Beside the consistent case law regarding this issue, it would also be very unwise if the Euratom Treaty had any intention of excluding the applicability of competition rules from the nuclear energy sector. Otherwise, in order to support nuclear development in line with the objectives of Euratom, anti-competitive behaviours, such as state aids might have taken place in the nuclear energy sector and this could distort the competition in the internal market. ${ }^{132}$ Moreover, it must be acknowledged that Article 101 and 102 of the TFEU, provisions regarding anti-competitive agreements and abuse of a dominant position, have also been consistently applied to nuclear energy ${ }^{133}$ which, therefore, leaves no room for doubt as to the applicability of state aid rules to the nuclear energy sector. Considering the Court's affirmative view in the recent Hinkley judgment and other convincing indicators which leave no doubt for the applicability of state aid rules, it could be expected that state aid rules will continue to be applied to the nuclear energy sector, taking into account the objectives of Euratom.

The second important issue concerning the applicability of state aid rules to nuclear energy concerns the compatibility assessment of nuclear state aids. The Commission, as discussed in section 2.3.1, has published several guidelines in which it laid down some common assessment principles to make its compatibility assessment. In this regard, several energy aid categories have been included in 'Guidelines on State aid for environmental protection and energy 2014-2020' however, nuclear energy is not included in these guidelines. The exclusion of nuclear energy from the guidelines, while it had been included in the Draft guidelines, could be related to the pressures of certain anti-nuclear Member States. ${ }^{134}$ Due to this exclusion, apart from some specific

129 Commission Decision of 4 April 2006 on the State Aid which the United Kingdom is planning to implement for the establishment of the Nuclear Decommissioning Authority (C(2006) 650) [2006] OJ L 268, para 78 (NDA Decision); Commission decision of 22 September 2004 on the State aid which the United Kingdom is planning to implement for British Energy plc (C(2004)3474) [2004] OJ L 142, para 239 (British Energy Decision 2004)

130 Stanescu (n 120) 228

131 Case T-356/15 Republic of Austria v European Commission [2018] ECLI:EU:T:2018:439, paras 72-78 (General Court Hinkley Judgment)

132 Hancher and Salerno (n 20) 639

133 Hancher and Klasse (n 20) 250

134 Szyszczak, 'State aid for energy infrastructure and nuclear power projects' (n 17) 28 
guidelines which may cover certain nuclear state aids, ${ }^{135}$ compatibility assessment of nuclear state aid is currently made directly according to Article 107(3) of TFEU.

The assessment of nuclear state aid cases directly under article 107(3) due to the exclusion from the guidelines might be considered as a victory for anti-nuclear Member States. It must be stated that if nuclear energy had been included in the guidelines, this would have provided much clarity and relief for states which grant state aid to the nuclear energy sector. ${ }^{136}$ However, the exclusion of nuclear energy from the guidelines brought unexpected outcomes in that as there are no guidelines which bind the discretion of the Commission, the Commission is now making it compatibility assessment in more flexible way. When makng its compatibility assessment directly under article 107(3), while it usually adheres to common assessment principles set out in other guidelines, ${ }^{137}$ the Commission may, when needed, use its discretion very broadly.

\subsection{Nuclear Energy State Aid Cases}

\subsubsection{German Reserves for nuclear power station waste management and decommissioning ${ }^{138}$}

A group of electricity generation and distribution companies in Germany submitted a letter to the European Commission in which they complained about German Income Tax Act Section 5(1) which had allegedly granted selective advantage to nuclear power plants. ${ }^{139}$ In Germany, companies were required by Commercial Code to constitute contingency reserves in order to cover their future statutory liabilities, if any. ${ }^{140}$ In accordance with the provision, nuclear power plant operators constituted reserves for radioactive waste disposal and decommissioning costs due to their duties stemming from the Nuclear Power Act. ${ }^{141}$ According to Section 5(1), these contingency reserves are exempt from tax. ${ }^{142}$ The complainants argued that the tax exemption for contingency reserves was giving selective advantage to nuclear power operators as the amounts reserved in the nuclear sector were huge and disproportionate to other reserves. ${ }^{143}$

\footnotetext{
35 Communication from the Commission - Guidelines on State aid for rescuing and restructuring non-financial undertakings in difficulty [2014] OJ C 249; Commission Communication relating to the methodology for analysing State aid linked to stranded costs [1997] OJ L 27

136 Jürgen Kühling and Corinne Ruechardt, 'Nuclear Energy Reloaded - New State Aid for an Old Industry' (2017) 8(9) Journal of European Competition Law \& Practice 561, 567

137 Hancher and Klasse (n 20) 252

138 Germany Reserves for nuclear power station waste management and decommissioning - State aid NN 137/01 [2001] OJ C 77/27 (Germany Reserves Commission Decision)

139 ibid 1-2

140 ibid 2-3

141 ibid 3

142 ibid

143 ibid 2
} 
The Commission refuted the arguments of the complainants because the Income Tax Act did not give selective advantage to nuclear power plant operators as the tax exemption was open to any undertakings obligated to constitute contingency reserves by law. ${ }^{144}$ The huge amounts of nuclear contingency reserves and accompanying significant tax advantages are a corollary of heavy liabilities of the nuclear power sector, and, therefore, any selective advantage accrued to nuclear energy operators is no more than other companies. ${ }^{145}$

The complainant appealed against the Commission decision arguing that the German Income Tax Act had given a concealed selective advantage to nuclear power plant operators. The Court of First Instance (CFI), in its judgment, ${ }^{146}$ accepted that tax exemption for contingency reserves constituted an advantage for companies as this measure relieved those companies from the burden they would normally have to bear. ${ }^{147}$ But, according to the CFI, the measure in question did not meet the selectivity requirement of state aid because all companies were able to benefit from the tax exemption. ${ }^{148}$ In line with the Commission, the CFI stressed that the mere fact that nuclear operators received more advantage than others would not entail selectivity. ${ }^{149}$ The complainants again appealed to the European Court of Justice (ECJ) to dismiss the judgment of the CFI, but the ECJ dismissed the action due to the lack of standing of the complainants. ${ }^{150}$

In this case, the complainants did not sufficiently support their claims of concealed selectivity or de facto selectivity. ${ }^{151}$ Even if they had supported their claims, they would not have been successful because given that the advantages of nuclear reserves were proportionate to their liabilities, the Commission and the Court naturally declined their claims as to the disproportionate advantage of nuclear operators. If nuclear operators had been able to reserve more than they had to, then this would have given them selective advantage. As stated in one of the previous notices of the Commission, ${ }^{152}$ incidental benefits resulting from general measures do not necessarily mean that they are selective, as clearly demonstrated in this case.

\footnotetext{
144 ibid 6

145 ibid

146 Case T-92/02 Stadtwerke Schwäbisch Hall GmbH, Stadtwerke Tübingen GmbH and Stadtwerke Uelzen GmbH v Commission of the European Communities [2006] ECLI:EU:T:2006:26

147 ibid para 52

148 ibid para 108

149 ibid

150 Case C-176/06 P Stadtwerke Schwäbisch Hall GmbH, Stadtwerke Tübingen GmbH and Stadtwerke Uelzen GmbH v Commission of the European Communities [2007] ECLI:EU:C:2007:730

151 Dietmar O. Reich, 'No Level Playing Field for Nuclear Power Reserves?' (2006) 5(2) European State Aid Law Quarterly 445,448

152 Commission Notice on the application of the State aid rules to measures relating to direct business taxation [1998] OJ C 384, para 14
} 


\subsubsection{British Energy}

British Energy plc (BE), which was the operator of certain nuclear power plants in the United Kingdom (UK), after decreasing electricity prices in 2002 due to the increasing competition in the electricity market, started to incur significant losses. ${ }^{153}$ In essence, lower prices affected BE significantly as nuclear power plants are very vulnerable to low prices due to their inflexibility stemming from their cost structure which consists of high investment but low operation cost. In order to keep BE afloat, the UK decided to apply a rescue aid package consisting of credit facilities and a state guarantee for BE 's loans. ${ }^{154}$ Then, this rescue package was notified to the Commission for state aid control.

In its assessment, the Commission examined if all the required state aid elements were present. Regarding the advantage element of state aid, the Commission stated that the credit facility granted by the UK was giving a benefit which BE could not have obtained under market conditions given the hardships and financial difficulties it faced. ${ }^{155}$ After the assessment, the Commission considered the rescue package to be involving state aid, and started to make its compatibility assessment. As state aid granted to BE was a sort of rescue aid, it was assessed under 'Guidelines on State aid for rescuing and restructuring non-financial undertakings in difficulty'. Having made the assessment under these guidelines, the Commission found the rescue aid subject to some conditions compatible with state aid rules. ${ }^{156}$ Accordingly, the UK undertook to inspect the aid and submit restructuring plans of British Energy to the Commission within 6 months. ${ }^{157}$

After having received BE's restructuring plan, the Commission commenced the second state aid investigation due to concerns that this restructuring plan might involve state aid. The restructuring plan consisted of 7 different measures and these measures were between BE, the UK Government, and BE creditors, including British Nuclear Fuel Limited (BNFL) which was a publicly owned company. ${ }^{158}$ The first restructuring measure was related to the funding of BE nuclear liabilities by the Government. ${ }^{159}$ This measure, as it had all the elements of state aid, was deemed as involving state aid, and assessed under the Rescue and Restructuring guidelines and was found compatible. Some other measures between creditors and BE were not found as involving state aid because they were not funded from public resources. ${ }^{160}$

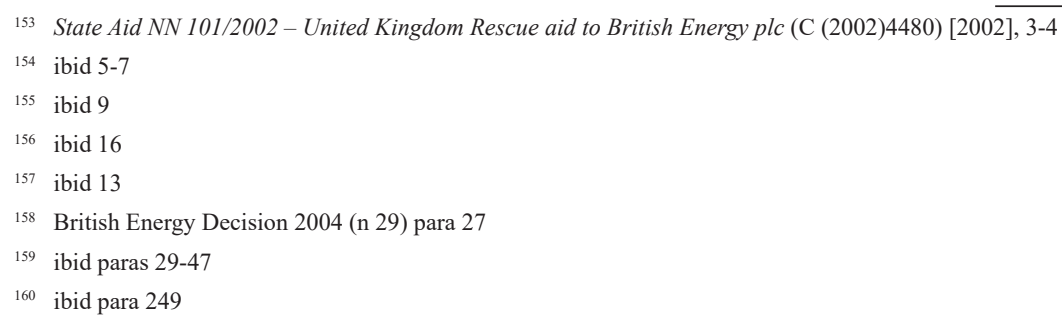


Lastly, measures between BE and BNFL in which parties were to renegotiate their contracts necessitated special assessment by the Commission. In line with the settled case law, the Commission did not automatically attribute the acts of the publicly owned undertaking BNFL to the state. The reason for this was that in order to be imputable, there must be some indicators which show that public authorities were actually involved in that act. The fact that BNFL had decided to renegotiate with $\mathrm{BE}$ before the UK Government had implemented the restructuring plan, showed that the acts of BNFL were not attributable to the state and therefore did not constitute state aid. ${ }^{161}$ In sum, only the first restructuring measure of funding BE nuclear liabilities was found to be compatible with state aid.

In terms of showing that some guidelines may still be applicable for some nuclear aid categories, British Energy decisions are important. In addition, the second British Energy decision clearly reiterated the settled case law on imputability of publicly owned undertakings' acts within the nuclear energy sector. The Commission stressed that there had to be some indicators showing the actual influence of public authorities for establishing that a public undertaking's acts are imputable to the state. And most importantly, these two British Energy decisions were important in terms of showing the increasing need of state aid for nuclear energy in competitive energy markets because it was clearly understood by the example of BE that nuclear power plant operators would face heavy burdens in competitive energy markets in the future without state aid. Unsurprisingly, nuclear state aid cases have risen all around Europe with the widening of competitive energy markets.

\subsubsection{EDF}

The Commission opened a state aid investigation in 2002 to look into advantages which Électricité de France (EDF) had been granted through non-payment of corporate tax due. ${ }^{162}$ These advantages originated from the restructuring of EDF's balance sheet in 1997, by which some of company's assets were excluded from taxation. France, as a sole shareholder of EDF, argued that this reclassification of taxable assets and ensuing unpaid taxes must be assessed as capital injection to the company. ${ }^{163}$ Therefore, this measure should be assessed as private investment of state in line with the market economy investor principle, not as state aid in the form of a tax waiver. However, the Commission rejected this argument by asserting that states cannot advance the private investor argument when they act within their public prerogative. ${ }^{164}$ In other words, according to the Commission, as tax regulation

161 ibid para 294

162 Commission Decision of 16 December 2003 on the State aid granted by France to EDF and the electricity and gas industries (notified under document number C (2003) 4637) [2005] OJ L 49, para 3

163 ibid para 45

164 ibid para 96 
is under the exclusive prerogative of the state, the private investor test cannot be applicable, simply because of the absence of comparable private investors in this area. Therefore, the Commission considered the restructuring of the balance sheet which gave selective advantage to EDF as involving incompatible state aid.

The decision of the Commission was appealed by EDF and France and went to the General Court (GC). ${ }^{165}$ They argued that the measure under the form of capital injection should be regarded as private investment in line with market conditions. ${ }^{166}$ According to them, as this private investment was in line with market conditions, it would consequently prevent the measure from being state aid because of the absence of any advantage for EDF. In its judgment, the GC firstly stated that only commercial activities of state can be compared to private investors, and, thus, the private investor test cannot be applied to the regulatory measures of states. ${ }^{167}$ But, for the GC, what is important for distinguishing commercial activities from regulatory measures of state is nature and object of the measure, not its form. ${ }^{168}$ Therefore, the GC annulled the Commission decision because of the erroneous formal approach of the Commission in which the Commission categorically excluded the application of the private investor test to regulatory measures of state without looking at the nature and object of the measure. For the GC, the Commission should have applied the private investor test to ascertain if France had behaved as a prudent investor when making these tax adjustments and capital injections. ${ }^{169}$

After the annulment of its decision, the Commission appealed the GC's judgment to the Court of Justice of European Union (CJEU). ${ }^{170}$ In its judgment, the CJEU firstly clarified the application of the private investor test. According to the CJEU, a Member State which relies on the test must bring verifiable evidence showing that the state had acted as a prudent private investor, before or at the same time taking the investment decision. ${ }^{171}$ Then, it is for the Commission to make its assessment by looking at the nature and objective of the measure, not at the form of the measure, in order to ascertain if the state had acted in its public capacity or as a shareholder. ${ }^{172}$ In the end, the appeal of the Commission was dismissed as the GC had not erred in finding that the private investor test should be applicable even when the state used tax regulations.

165 Case T-156/04 Électricité de France (EDF) v European Commission [2009] ECR II-04503

166 ibid paras 156-194

167 ibid para 224

168 ibid para 229

169 ibid para 249

170 Case C-124/10 P European Commission v Électricité de France (EDF) [2012] ECLI:EU:C: 2012:318

171 ibid paras $82-83$

172 ibid para 86 
After the CJEU upheld the GC's judgment, the Commission made a new extension decision regarding the annulment reasons of its decision. ${ }^{173}$ On this occasion, the Commission applied the private investor test to the tax measure of the state. In doing so, the Commission examined all verifiable evidence submitted by France which could show that the measure had been taken out of private investment motives. However, the Commission could not verify that France acted as a private investor. ${ }^{174}$ In the end, this tax measure was found to be incompatible state aid. While EDF appealed this decision, this time it was dismissed on the grounds that the Commission had not erred in applying the private investor test. ${ }^{175}$

The insistence of the Commission in the first leg of the process was essentially a reflection of the classic approach in which the role of the state as a public authority and the role of state as a commercial actor are strictly separated. ${ }^{176}$ According to the classic approach, it is impossible for the Commission to apply the private investor test within this sphere as taxation is under the sole competence of state. This approach was also defended by the Advocate General due to the legal clarity of this approach. ${ }^{177}$ It may also be added that the approach taken by the GC and adopted by the CJEU could increase the workload of the Commission, ${ }^{178}$ because, due to this new approach, the Commission would have to apply the private investor test even where states used fiscal measures.

However, it must be acknowledged that this new approach is the natural extension of the functional approach taken by the Courts in state aid control. ${ }^{179}$ In that sense, the Court, indeed, had showed its willingness to apply the functional approach in the Ryanair case ${ }^{180}$ where the form of the measure was not taken into consideration in applying the private investor test. With the EDF cases, it was decisively confirmed that the form of the state measure was no longer relevant in determining the application of the private investor test. This will likely increase the application of the private investor test in future nuclear state aid cases and this will likely make state aid control more effective in the future.

\footnotetext{
173 Commission Decision (EU) 2016/154 of 22 July 2015 on State aid SA.13869 (C 68/2002) (ex NN 80/2002) - reclassification as capital of the tax-exempt accounting provisions for the renewal of the high-voltage transmission network (RAG) implemented by France in favour of EDF (notified under document C(2015) 4959) [2015] OJ L 34

174 ibid para 154

175 Case T-747/15 Électricité de France (EDF) v European Commission [2018] ECLI:EU: T: 2018:6

176 Szyszczak, 'The Survival of the Market Economic Investor Principle in Liberalised Markets' (n 19) 36

177 Case C-124/10 P European Commission v Électricité de France (EDF) [2011] ECR 2012 -00000, Opinion of Mr Advocate General Mazák, para 77

178 Sebastien Thomas, 'The EDF judgment of the CJEU in case C-124/10 P: towards a public investor test in EU State aid law?' (European Law Blog 2012) <https://europeanlawblog.eu/2012/09/18/the-edf-judgment-of-the-cjeu-in-case-c-12410p-towards-a-public-investor-test-in-eu-state-aid-law/> accessed 23 August 2020

179 Szyszczak, 'The Survival of the Market Economic Investor Principle in Liberalised Markets' (n 19) 37

${ }^{180}$ Case T-196/04 Ryanair Ltd v Commission of the European Communities [2008] ECR II-03643, para 101
} 


\subsubsection{Hinkley Point $\mathrm{C}$}

The United Kingdom notified the Commission concerning certain measures with respect to the Hinkley Point $\mathrm{C}$ nuclear power plant which was to be built by EDF. These measures consisted of a Contract for Difference (CfD), a state credit guarantee and a secretary of state agreement. According to the $\mathrm{CfD}$, which was an agreement between NNB Generation Company (NNBG) controlled by EDF and state-owned Low Carbon Contracts Company, NNBG would sell its electricity into the market and would receive another payment from the CfD counterparty equivalent to the difference between the market price (reference price) and determined strike price. ${ }^{181}$ If the strike price was above the reference price, then the difference was to be paid to NNBG. ${ }^{182}$ Thanks to this mechanism, NNBG stabilised its revenue and minimised market risks. The second measure was the state credit guarantee by which state would guarantee timely payment of bonds issued by NNBG. ${ }^{183}$ With the last measure, the Secretary of State gave a guarantee to investors that they would be compensated if a nuclear power plant were to close on political grounds and if the CfD counterparty defaulted on compensation payments. ${ }^{184}$

Having been notified by the UK, the Commission opened a state aid investigation for these measures. The UK initially defended their argument that these measures did not involving state aid because these measures were provided as compensation for SGEI based on the Altmark criteria. ${ }^{185}$ The Commission did not accept this defence because, in order to comply with Altmark, there must be a clearly defined assignment of public service and this must entrust an undertaking with the obligation to provide that service. ${ }^{186}$ However, according to the CfD, there was no obligation for NNBG to provide electricity and sell it to the state. After having rejected the SGEI defence, the Commission went on to examine these measures under article 107(1) in terms of whether they involved state aid for NNBG. With respect to the Secretary of State Agreement, EDF and the UK contended that the right to compensation was a general right of private investors when their property rights are breached, therefore this measure did not entail any advantage. ${ }^{187}$ However, the Commission explicitly stated that as this special agreement relieved the NNBG investor from spending time and fees by resorting to general compensation mechanisms used by other investors, this would entail an advantage for investors in NNBG. ${ }^{188}$ Regarding the credit guarantee, the Commission found that the price paid by NNBG for the guarantee was below

181 Hinkley Decision (n 123) paras 6-8

182 ibid para 9

183 ibid paras 48-49

184 ibid paras $74-75$

185 ibid

186 ibid paras 290-291

187 ibid paras 319-320

188 ibid para 322 
the market price which would again entail an advantage for NNBG. ${ }^{189}$ After all examinations, three UK measures in favour of NNBG were found to involve state aid by the Commission. ${ }^{190}$

As nuclear energy is not included in the 'Guidelines on State aid for environmental protection and energy 2014-2020', the compatibility assessment of nuclear state aid cases is usually made directly under article 107(3)(c). In its assessment, the Commission firstly stated that state measures which are intended to maintain the current situation or relieves undertakings' operational costs, namely operating aids, are not, in principle, compatible ${ }^{191}$ because, only aids which facilitates the development of certain economic activities are allowed under article 107(3)(c). In that sense, while the measures of the UK Government, such as the CfD which stabilised NNBG's revenue, seemed as if they did involve operating aid, the Commission likened these measures to investment aid because these measures were, in essence, intended to facilitate the investment. ${ }^{192}$ In other words, the Commission did not take into consideration the form of aids, instead, their effects were considered.

As a compatibility condition, a measure must pursue objectives of common interest under article 107(3)(c). In this regard, the Commission accepted the promotion of nuclear energy as an objective of common interest taking into consideration the objectives of the Euratom Treaty. ${ }^{193}$ Then, with respect to the other condition of necessity, the Commission investigated the existence of market failures relevant to the nuclear energy sector. In that sense, the Commission pointed out the high upfront costs and long recovery times which make nuclear power plant operators vulnerable to market risks and therefore compelling them to hedge these risks with various financial instruments. ${ }^{194}$ In the same vein, the Commission accepted the necessity of CfD type risk hedging instruments for nuclear energy investments given the scarcity of long time hedging instruments. ${ }^{195}$ After all of these compatibility assessments, the Commission concluded that any potential distortion of competition of the UK's measures was limited and offset by their positive effects. Therefore, UK state aid measures were found compatible, and were subject to certain amendments, under article $107(3)(\mathrm{c}) .{ }^{196}$

\footnotetext{
189 ibid para 338

190 ibid para 342

191 ibid para 344

192 ibid para 346

193 ibid paras 369-374

194 ibid para 382

195 ibid para 382

196 ibid para 550
} 
After the Commission's affirmative decision, very exceptionally, ${ }^{197}$ another Member State, Austria, contested the decision. While Luxemburg supported Austria in this action, ${ }^{198}$ other Member States, such as France, Hungary, Poland, and Slovakia intervened in favour of the United Kingdom. ${ }^{199}$ Due to the extensive controversy around the case, the GC had to touch upon nearly all aspects of state aid law which, therefore, has made this judgment one of the longest in state aid history. However, there were some important points in the judgment which have put the Hinkley case in a very special position within state aid case law.

Firstly, the GC laid down its view on the applicability of state aid rules to the nuclear energy sector and concluded that the state aid rules are applicable to nuclear energy taking into consideration the objectives of Euratom. ${ }^{200}$ During the appeal, Austria maintained that promoting nuclear energy cannot be accepted as an objective of common interest, considering the anti-nuclear sentiments of some Member States, therefore it is not possible to find any nuclear state aid which is compatible with article 107(3)(c). ${ }^{201}$ However, the Court made a very important interpretation regarding the phrase 'common' interest, stating that the objective of common interest does not have to be the objective shared by all or the majority of Member States. ${ }^{202}$ With reference to its previous case law, the Court stated that measures pursuing public interest, not private interest of aid beneficiary, can be deemed as pursuing objective of common interest. ${ }^{203}$ With this broad interpretation, the Court has widened the meaning of the objective of common interest. However, this new interpretation is unnecessary for nuclear energy because of the special position of Euratom according to which promoting nuclear energy is already an objective of common interest as accepted by the Commission.

Austria also argued that the Commission's explanations with respect to market failures which made these measures compatible were erroneous. ${ }^{204}$ Moreover, during the appeal, Austria challenged the Commission's view of accepting these measures as involving investment aid instead of operating aid. ${ }^{205}$ However, the Court refused these claims and upheld the Commission's decision, stating that the compatibility assessment under article 107(3)(c) does not necessarily require finding a market

\footnotetext{
Leigh Hancher, 'State Aid to the Nuclear Power Sector: The General Court's Ruling on the UK Reactor at Hinkley Point C' (2018) OGEL, 5 <https://www.sipotra.it/wp-content/uploads/2019/02/State-Aid-to-the-Nuclear-Power-Sector-TheGeneral-Courts-Ruling-on-the-UK-Reactor-at-Hinkley-Point-C.pdf> accessed 23 August 2020

198 General Court Hinkley Judgment (n 131), 1

199 ibid 1-2

$200 \quad$ ibid para 78

$201 \quad$ ibid para 69

202 ibid para 84

$203 \quad$ ibid para 86

204 ibid para 147

205 ibid para 576
} 
failure ${ }^{206}$ nor does it necessarily exclude operating aid. ${ }^{207}$ This is because, as the Court explained, these are requirements specified only in the guidelines but article 107(3)(c) does not necessarily require the existence of market failure or there being investment aid in order to find nuclear state aid compatible. ${ }^{208}$ The Court's here clearly supported the flexibility of the Commission when making its nuclear state aids compatibility assessment directly under article 107(3)(c) instead of under the guidelines.

Considering the positive decision and the judgment, it could be expected that this case, which allows the granting of huge amounts of state aids, will be a precedent for other states planning to use state aid to further their nuclear development policies. Also, this case has clearly demonstrated how the Commission and the Court appreciated the very specific risks of the nuclear sector and accordingly behaved leniently with respect to state aid measures to the nuclear energy sector. Even though any nuclear state aid case is assessed on its basis as there is not one specific guideline for nuclear energy, in light of the previous cases and Hinkley, it is very clearly seen that nuclear energy cases are treated differently by the Commission and the Courts. This lenient treatment will likely remain as long as the Euratom Treaty and market failures and risks for the nuclear energy sector exist.

\subsubsection{The Paks II Nuclear Power Station ${ }^{209}$}

Hungary planned to finance the construction of new nuclear power units which would be owned and operated by the state owned Paks II company. ${ }^{210}$ In response, the Commission started a state aid investigation into the financing of this nuclear power construction. Hungary mainly defended the non-existence of aid regarding its financing measures and claimed that it acted as a private investor and sought to make profit from this investment. ${ }^{211}$ The private investor test, or market economy investor principle (MEIP), is a recognised principle which examines whether or not a private investor would have invested under the same conditions in which the state invested. ${ }^{212}$ For a private investor, basically, the internal rate of return (IRR) of the project must be higher than the weighted average cost of capital (WACC) of the project. ${ }^{213}$ If the IRR is higher than the WACC, then it can be accepted that a private investor would have invested in the project. In accordance with this test, Hungary asserted that the IRR was higher than the WACC and accordingly, this measure

\footnotetext{
206 ibid para 150

207 ibid para 583

208 ibid para 151

209 Commission Decision (EU) 2017/2112 of 6 March 2017 on the measure/aid scheme/State aid SA.38454 (C/2017/1486) [2017] OJ L 317 (Hungary Paks II Decision)

210 ibid para 52

211 ibid

212 ibid para 53

213 ibid para 54
} 
would not give any advantage to Paks II and this would prevent the measure from being state aid. ${ }^{214}$

However, the Commission decided to calculate its own estimation with respect to the IRR and WACC in order to make sure that a private investor would have invested under the same conditions. In doing so, the Commission took an important step ${ }^{215}$ and provided a range of benchmarks instead of providing exact figures for the IRR or WACC due to the inherent uncertainty of the nuclear energy sector. ${ }^{216}$ Based on its own calculations, the Commission concluded that the expected internal return of the project was not higher than the capital cost of the project and therefore a private investor would not have invested under these conditions. ${ }^{217}$ As the measure of state did not pass the private investor test, this meant that the measure gave an advantage to Paks II. Having established the advantage element and other required elements of state aid, the state measure to finance the construction of new nuclear units was deemed as involving state aid. However, the Commission made its compatibility assessment under article 107(3) and found this measure compatible as the objectives of the measure outweighed the potential distortions of the competition. ${ }^{218}$

The Court had widened the scope of application of private investor test in the earlier EDF judgment, and with this Paks II decision, the Commission clarified how to apply this test especially for the nuclear energy sector so that it could give more accurate results. Moreover, this case showed the possibility that states may be involved in the construction of new nuclear power plants as a private investor under market conditions. Therefore, it is likely that states planning to build their own nuclear plant will bring the private investor test argument more frequently in the future in order to avoid state aid control of the Commission.

\section{Conclusion}

This research is based on the premises that state aid cases to nuclear energy have increased significantly within the last decade and in parallel to this increase, controversy about state aid being granted to the nuclear energy sector has soared. In addition to this popularity, the existence of the special treaty, Euratom, exclusion of nuclear energy from the 'Guidelines on State aid for environmental protection and energy 2014-2020' and the numerous risks and market failures related to the nuclear energy sector distinguish nuclear state aid cases from other energy state aid cases. Given its distinctness and increasing importance, the intention of this research was to

215 Adina Claici and Norbert Maier, 'State Aid for Electricity in Hungary - New Insights into the MEIP Test' (2019) 2019 Eur St Aid LQ 76, 82-83

216 Hungary Paks II Decision (n 209) para 206

217 ibid paras 261-262

218 ibid para 391 
focus on the relationship between state aid and the nuclear energy sector and analyse prominent nuclear state aid cases. In this research, it was asked what the relationship between state aid and nuclear is, how nuclear energy state aid cases have been dealt with and how does the case law provide an outlook for the future.

With the Germany Contingency Reserves case, the content of selectivity, one of the main requirements of establishing state aid, was clarified. It was explicitly reiterated that the fact that an undertaking gets more benefit incidentally than other undertakings, thanks to the state measure, which is applied equally to all undertakings, does not necessarily make concerning state measure selective. Accordingly, it was settled that the important thing which prevents state measures from being selective is to set equal criteria for undertakings to benefit from state measures instead of dealing with them as if all undertakings equally benefited from the state measure.

In the British Energy decisions, it was clearly understood that there is an increasing need for state aid to nuclear power plants as energy markets become more competitive. It has been understood that low prices and lack of financial instruments which could hedge market risks for a long time could expose nuclear power plant operators to unbearable challenges, as happened to British Energy. After the British Energy decisions, as expected, numbers of nuclear state aid cases have soared due to the rises in the various risks stemming from increasingly competitive energy market conditions.

The most important advancement of state aid law was achieved thanks to the long EDF cases by which the scope of the private investor test was widened. After the EDF cases, it was settled that, even if a state measure were a regulatory measure, the Commission would have to investigate if the private investor test were applicable. In other words, the Commission will have to look at the effect of the measure, not its form. In the same vein, after the EDF cases, the Commission made a very important decision in Hungary Paks II as to the content of the private investor test and showed how the private investor test should be applied within nuclear energy state aid cases, taking into consideration the uncertainties of the nuclear energy sector in order to attain more accurate results. Thanks to these important cases which clarified and developed the private investor test, it might be expected that states will be more likely to participate in works in the nuclear energy sector more often as a private investor and they could frequently use the private investor test in order to prove that their investments do not give any advantage.

When it comes to the most controversial case of nuclear state aid history, the Hinkley case, the main discussions were around the separation of investment and operating aid. While the state measures for Hinkley, such as the CfD, at first glance, seemed like operating aid, the Commission decided to look deep inside and then 
accepted these measures as if they were investment aid. As these state measures were accepted as investment aid, they were found compatible with state aid rules. It has to be accepted that the Commission's effect-based stance is a very important advancement within case law, and it is likely to encourage other states to use different state aid mechanisms similar to the $\mathrm{CfD}$ in order to minimise risks for private investors.

Considering all of the above, it could be concluded that the issue of the application of state aid rules to the nuclear energy sector is mostly settled and that nuclear state aids will continue to be controlled under state aid rules, taking into account the objectives of the Euratom Treaty. It might be expected that numbers of nuclear state aid cases will likely continue to increase as energy markets become more competitive. However, it is patently clear that the intrinsic risks in the nuclear energy sector and related market failures stemming from imperfect market conditions are keenly appreciated by the Commission and the Courts, and nuclear power sector cases are treated more leniently in line with these conditions. This sends a very clear message that the lenient approach of the Commission and the Courts toward nuclear state aid cases will continue as long as market failures and the Euratom treaty exist and in this regard, the absence of guidelines for nuclear energy, while it seems like a disadvantage, will ensure the needed flexibility of the Commission when making its state aid assessments in nuclear state aid cases.

Peer-review: Externally peer-reviewed.

Conflict of Interest: The author has no conflict of interest to declare.

Grant Support: The author declared that this study has received no financial support. 


\section{Bibliography/Bibliyografya}

\section{Primary Sources}

\section{Cases}

Case C-124/10 P. European Commission v Électricité de France (EDF) [2012] ECLI:EU:C: 2012:318.

Case T-356/15 Republic of Austria v European Commission [2018] ECLI:EU: T: 2018:439

Case 30/59 De Gezamenlijke Steenkolenmijnen in Limburg v High Authority of the European Coal and Steel Community [1961] ECR 1

Case C-83/98 P French Republic v Ladbroke Racing Ltd and Commission of the European Communities [2000] EU:C:2000: 248

Case 173-73 Italian Republic v Commission of the European Communities [1974] ECR 709

Case C-379/98 Preussen Elektra AG v Schhleswag AG [2001] ECR I-2159

Case C-482/99 French Republic v Commission of the European Communities [2002] ECR 2002 I-04397

Case T-358/94 Compagnie Nationale Air France v Commission of the European Communities [1996] ECR II-02109

Case C-241/94 French Republic v Commission of the European Communities [1996] ECR I-04551

Case C-487/06 P British Aggregates Association v Commission of the European Communities and United Kingdom [2008] ECR I-10515

Joined Cases C-78/08 to C-80/08 Ministero dell'Economia e delle Finanze and Others $v$ Paint Graphos Soc. coop. arl and Others [2011] ECR I-07611

Case C-88/03 Portuguese Republic v Commission of the European Communities [2006] ECR I-07115

C-39/94 Syndicat français de l'Express international (SFEI) and others $v$ La Poste and others [1996] ECR I-3547

Case T-288/97 Regione Friuli Venezia Giulia v Commission of the European Communities [2001] ECR II-01169

Cases 730/79 Philip Morris Holland BVv Commission of the European Communities [1980] ECR-02671

Joined cases T-447/93, T-448/93 and T-449/93 Associazione Italiana Tecnico Economica del Cemento and British Cement Association and Blue Circle Industries plc and Castle Cement Ltd and The Rugby Goup plc and Titan Cement Company SA v Commission of the European Communities [1995] II-01971

Case T-214/95 Het Vlaamse Gewest (Flemish Region) v Commission of the European Communities [1998] II-00717

Case C-351/98 Kingdom of Spain v Commission of the European Communities [2002] I-08031

Case T-101/18 Action brought on 21 February 2018 - Austria v Commission [2018] OJ C 152

Case T-92/02 Stadtwerke Schwäbisch Hall GmbH, Stadtwerke Tübingen GmbH and Stadtwerke Uelzen GmbH v Commission of the European Communities [2006] ECLI:EU:T:2006:26

Case C-176/06 P Stadtwerke Schwäbisch Hall GmbH, Stadtwerke Tübingen GmbH and Stadtwerke Uelzen GmbH v Commission of the European Communities [2007] ECLI:EU:C:2007:730

Case T-156/04 Électricité de France (EDF) v European Commission [2009] ECR II-04503 
Case T-196/04 Ryanair Ltd v Commission of the European Communities [2008] ECR II-03643

Case T-747/15 Électricité de France (EDF) v European Commission [2018] ECLI:EU: T: 2018:6

Case C-124/10 P European Commission v Électricité de France (EDF) [2011] ECR 2012 -00000, Opinion of Mr Advocate General Mazák

Commission Decision (EU) 2016/154 of 22 July 2015 on State aid SA.13869 (C 68/2002) (ex NN 80/2002) - reclassification as capital of the tax-exempt accounting provisions for the renewal of the high-voltage transmission network (RAG) implemented by France in favour of EDF (notified under document C(2015) 4959) [2015] OJ L 34

Commission Decision (EU) 2017/2112 of 6 March 2017 on the measure/aid scheme/State aid SA.38454 (C/2017/1486) [2017] OJ L 317

Commission Decision of 16 December 2003 on the State aid granted by France to EDF and the electricity and gas industries (notified under document number C (2003) 4637) [2005] OJ L 49

Germany Reserves for nuclear power station waste management and decommissioning - State aid NN 137/01 [2001] OJ C 77/27

State Aid NN 101/2002 - United Kingdom Rescue aid to British Energy plc (C (2002)4480) [2002]

Support to Hinkley Point C Nuclear Power Station (2014/C 69/06) Commission Decision SA.34947 [2014] OJ C/69

Commission Decision of 4 April 2006 on the State Aid which the United Kingdom is planning to implement for the establishment of the Nuclear Decommissioning Authority $(\mathrm{C}(2006) 650)$ [2006] OJ L 268

Commission decision of 22 September 2004 on the State aid which the United Kingdom is planning to implement for British Energy plc (C(2004)3474) [2004] OJ L 142

\section{Legislations}

Consolidated version of the Treaty on the Functioning of the European Union [2012] OJ C 326

Consolidated version of the Treaty establishing the European Atomic Energy Community [2012] OJ C 327

Commission Notice on the notion of State aid as referred to in Article 107(1) of the Treaty on the Functioning of the European Union [2016] OJ C 262

Commission Regulation (EU) No 1407/2013 of 18 December 2013 on the application of Articles 107 and 108 of the Treaty on the Functioning of the European Union to de minimis aid Text with EEA relevance [2013] OJ L 352

Communication from the Commission - Guidelines on State aid for environmental protection and energy 2014-2020 [2014] OJ C 200/01 (Guideline for environmental protection and energy 2014-2020)

Guidelines on regional State aid for 2014-2020 Text with EEA relevance [2013] OJ C 209

Communication from the Commission on the application of the European Union State aid rules to compensation granted for the provision of services of general economic interest Text with EEA relevance [2012] OJ C 8/02 SGEI Communication

2012/21/EU: Commission Decision of 20 December 2011 on the application of Article 106(2) of the Treaty on the Functioning of the European Union to State aid in the form of public service compensation granted to certain undertakings entrusted with the operation of services of general economic interest (notified under document C(2011) 9380) Text with EEA relevance [2011] OJ L 7 
Communication from the Commission - European Union framework for State aid in the form of public service compensation (2011) Text with EEA relevance [2012] OJ C 8/03

Communication from the Commission - Guidelines on State aid for rescuing and restructuring non-financial undertakings in difficulty [2014] OJ C 249

Commission Communication relating to the methodology for analysing State aid linked to stranded costs [1997] OJ L 27

Commission Notice on the application of the State aid rules to measures relating to direct business taxation [1998] OJ C 384

\section{Secondary Sources}

\section{Books}

Anchustegui H I and Bergqvist C, 'The role of State aid law in energy' in Tina Hunters and others (eds), Handbook of Energy Law (Routledge 2020)

Bacon K, European Union Law of State Aid (3rd edn, Oxford University Press 2017)

Bartosch A, 'The Concept of Selectivity' in Erika Szyszczak (ed), Research Handbook on European State Aid Law (Edward Elgar 2011)

Biondi A and Righini E, 'An Evolutionary Theory of State Aid Control' in Damian Chalmers and Anthony Arnull (eds), The Oxford Handbook of European Union Law (Oxford University Press 2015)

Biondi A and Stefan O, 'The Notice on the Notion of State Aid: Every Light Has Its Shadow' in Bruno Nascimbene and Alessia Di Pascale (eds), The Modernisation of State Aid for Economic and Social Development (Studies in European Economic Law and Regulation 14, Springer 2018)

Caoimh O A and Sauter W, 'Criterion of Advantage' in Herwig C H Hofmann and Claire Micheau (eds), State Aid Law of the European Union (Oxford University Press 2016)

Graham C, EU and UK Competition Law ( $2^{\text {nd }}$ edn, Pearson 2010)

Hancher L and Klasse M, 'Aid to Nuclear and Coal' in in Leigh Hancher and others (eds), State Aid and the Energy Sector (Bloomsbury 2018)

Hancher L and others, EU State Aids ( $5^{\text {th }}$ edn, Sweet \& Maxwell 2016)

Hancher L and Salerno F, 'Coal and Nuclear Aid' in Christopher Jones (ed), EU Energy Law, Volume II: Competition Law and Energy Markets ( $5^{\text {th }}$ edn, Claeys \& Casteels 2019)

López P J J, The Concept of State Aid Under EU Law: From internal market to competition and beyond (Oxford University Press 2015)

Nykiel-Mateo A and Wiemann J, 'Selectivity' in Nicola Pesaresi and others (eds), EU Competition Law (Volume 4 Book 1, ${ }^{\text {nd }}$ edn, Claeys Casteels 2016)

Orzan F M, 'De Jure Compatible Aid under Article 107(2) TFEU in Herwig C H Hofmann and Claire Micheau (eds), State Aid Law of the European Union (Oxford University Press 2016)

Padilla J and Haegler U, 'Compensation for SGEI: An Economist's Look at the Altmark Test and the Community Framework' in Jacques Derenne and Massimo Merola (eds), Economic Analysis of State Aid Rules- Contributions and Limits- (Lexxion 2007)

Petersen F C, Award of Public Contracts as a Means to Conferring State Aid: A Legal Analysis of the Interface Between Public Procurement Law and State Aid Law (PhD series Number 10.2018, Copenhagen Business School 2018)

Schoning F and Ziegler C, 'What is State Aid?' in Leigh Hancher and others (eds), State Aid and the Energy Sector (Bloomsbury 2018) 
Slot J P, 'EU State Aids Law' in Dennis Patterson and Anna Södersten (eds), A Companion to European Union Law and International Law (Wiley 2016)

Szyszczak E, 'Criterion of State Origin' in Herwig C H Hofmann and Claire Micheau (eds), State Aid Law of the European Union (Oxford University Press 2016)

Thomas S, The Economics of Nuclear Power: An Update (Publication Series on Economy, Heinrich-Böll-Stiftung 2010)

Whish R and Bailey D, Competition Law ( $8^{\text {th }}$ edn, Oxford University Press 2015)

\section{Journal Articles}

Bacon K, 'State Aids and General Measures' (1997) 17(1) Yearbook of European Law 269

Biondi A, "Some Reflections on the Notion of "State Resources" in European Community State Aid Law' (2006) 30 Fordham Int'l L.J. 1426

Bouchagiar A, 'The Binding Effects of Guidelines on the Compatibility of State Aid: How Hard is the Commission's Soft Law?' (2017) 8(3) Journal of European Competition Law \& Practice 157

Claici A and Maier N, 'State Aid for Electricity in Hungary - New Insights into the MEIP Test' (2019) 2019 Eur St Aid LQ 76

Clayton M and Catalan S J M, 'The Notion of State Resources: So Near and yet So Far' (2015) 14(2) European State Aid Law Quarterly 260

Cornella S, 'The Market Economy Investor Principle to Evaluate State Aid: Latest Developments and New Perspectives' (2015) 22 Maastricht J Eur \& Comp L 553

Ferro S M, 'Competition Law and the Nuclear Sector: An EU Outlook' (2011) 2010(2) Nuclear Law Bulletin 13

Kühling J and Ruechardt C, ‘Nuclear Energy Reloaded - New State Aid for an Old Industry' (2017) 8(9) Journal of European Competition Law \& Practice 561

Prek M and Lefèvre S, 'The Requirement of Selectivity in the Recent Case-Law of the Court of Justice' (2012) 11(2) European State Aid Law Quarterly 335

Reich O D, 'No Level Playing Field for Nuclear Power Reserves?' (2006) 5(2) European State Aid Law Quarterly 445

Robins N and Chakma T, 'State Aid in Energy under the Spotlight' (2016) 15(2) European State Aid Law Quarterly 247

Stanescu G C, 'Stabilization Mechanisms for Nuclear Investments vs. Electricity Market Liberalization: The Case of Contract for Difference. Lessons from the United Kingdom and Romania' (2018) 27(6) European Energy and Environmental Law Review 223

Szyszczak E, 'The Survival of the Market Economic Investor Principle in Liberalised Markets' (2011) 10(1) European State Aid Law Quarterly 35

Szyszczak E, 'State aid for energy infrastructure and nuclear power projects' (2015) 16 ERA Forum 25

Thomas S, 'Competitive energy markets and nuclear power: Can we have both, do we want either?' (2010) 38 Energy Policy 4903

Tromans S, 'State support for nuclear new build' (2019) 12(1) The Journal of World Energy Law \& Business 36

\section{Online Sources}

European Commission, 'State Aid Scoreboard 2019'<https://ec.europa.eu/competition/state_aid/ scoreboard/state_aid_scoreboard_2019.pdf $>$ accessed 19 August 2020 
Hancher L, 'State Aid to the Nuclear Power Sector: The General Court's Ruling on the UK Reactor at Hinkley Point C' (2018) OGEL <www.sipotra.it/wp-content/uploads/2019/02/State-Aidto-the-Nuclear-Power-Sector-The-General-Courts-Ruling-on-the-UK-Reactor-at-HinkleyPoint-C.pdf $>$ accessed 23 August 2020

Karim R Md, 'The EU Market Economy Investor Principle: A Good Paradigm?' (2014) <https:// papers.ssrn.com/sol3/papers.cfm?abstract_id=2498873 $>$ accessed 21 August 2020

Sauter W, 'The Criterion of Advantage in State Aid: Altmark and Services of General Economic Interest' $(2014)<$ https://ssrn.com/abstract=2426230 > accessed 22 August 2020

Thomas S, 'The EDF judgment of the CJEU in case C-124/10 P: towards a public investor test in EU State aid law?' (European Law Blog 2012) <https://europeanlawblog.eu/2012/09/18/ the-edf-judgment-of-the-cjeu-in-case-c-12410-p-towards-a-public-investor-test-in-eu-state-aidlaw/> accessed 23 August 2020

Tromans S, 'Subsidies for Nuclear Power in the UK: Putting the Debate into the Context' (2014) < https://www.39essex.com/docs/articles/nuclear_power_and_subsidies_january_2014_final.pdf $>$ accessed 22 August 2020 
